\title{
EFFECTS OF REMITTANCES ON POVERTY REDUCTION: THE CASE OF INDONESIA
}

\author{
Faiza Husnayeni Nahar \\ Faculty of Economics and Business, Universitas Muhammadiyah Yogyakarta, Indonesia \\ (faizahusnayeni@umy.ac.id)
}

Mohd Nahar Mohd Arshad

Faculty of Economics and Management Sciences, International Islamic University Malaysia, Malaysia

(ma.nahar@iium.edu.my)

\begin{abstract}
Remittances have been reported as a tool for fighting poverty in some selected countries, such as Indonesia. An increase of income through remittances tends to improve the economic status of the migrant's household. Once they get a high salary, they will remit money (a remittance) to their household in Indonesia via formal institutions, such as banks. The migrant's household can fulfil their basic needs and can use the remittance for educational investment and productive activities. The education investment aims to educate the children or grandchildren of migrants, which will be beneficial for the future generations of the family, allowing them the chance of a more prosperous life. The poverty rate would be reduced gradually, and economic welfare can be achieved. The main objectives of this paper are first to estimate the effects of remittances on poverty in Indonesia from 1983 to 2015 and second, to propose several strategic policies related to remittances and poverty reduction. Other variables considered include inflation, exchange rates, income, income inequality and the labor force participation rate. An Ordinary Least Square (OLS) method was used to explore the econometric and estimated results. The study found that an increase in remittances led to a reduction in poverty by $2.56 \%$. Inflation and the exchange rate have positive and negative effects on poverty, respectively. The small effect of remittances on poverty's reduction could possibly be explained by the low educational background of the migrants, low wage jobs, expensive remittance costs, and migrants not knowing how to remit money through formal financial institutions. Hence, to reduce the poverty level, the government needs to first facilitate skills training for the workers so that they could get a better job and earn more, second, lower the transaction costs of remittances, and lastly, provide agents at Indonesian banks overseas to provide better facilities to Indonesian workers to remit money back to their home country.
\end{abstract}

Keywords: remittance, poverty, Indonesia, OLS.

\section{INTRODUCTION}

More than 215 million people worldwide cross borders to work abroad (World Bank, 2011). They migrate to improve their economic conditions. Stark and Bloom (1985), as cited by the Asian Development Bank (1992), reported that international migration is the solution for solving the limitations that exist in an individual's home country. The lack of job opportunities, huge population, low-incomes, a big gap in income levels between rural and urban areas, poverty, and inequality in the distribution of income are some of the reasons that trigger migration. Hence, international migration will benefit the migrants, especially the migrants' households, by improving their living standards through income increments and the risk minimization that comes from that income (Massey, Arango, Hugo, \& Kouaouci, 1993).

According to the World Bank (2011), in 2010 , the country that sent the most migrants, was Mexico, with about 11.9 million workers, followed by India with around 11.4 million 
people, and the Russian Federation sending 11.1 million people. The ASEAN region has also sent a large number of workers overseas. Indonesia has been sending significant numbers of migrant workers, along with the other ASEAN countries (World Bank, 2011). As the world's fourth largest population, with about 237.6 million people in 2010 (Asian Development Bank, 1992), Indonesia sent approximately 2.5 million migrant workers in 2010 (World Bank, 2011); it is the country that sends the second most migrants from among the ASEAN countries, after the Philippines, which sent about 4.7 million migrants (World Bank, 2011).

Recently, the number of migrants from Indonesia has shown a declining trend. The decrease in the number of migrants is due to: (i) The reduction in the number of workers sent to the Middle East and (ii) the reduction in the number of unskilled workers in Indonesia. It was reported that the number of Indonesian workers who migrated to the United Arab Emirates declined from 2012 to 2015, with 35,888 and 7,619 people sent respectively (BNP2TKI, 2015).

The main reason that drives the majority of the Indonesian workers to migrate outside of their home country is the economic problems they face there. Most of the workers could not cover their basic needs in the proper way, due to their insufficient salary or unemployment. The lack of job opportunities, especially for unskilled workers, will cause arise in the unemployment and underemployment rates in Indonesia. In 2016, the number of unemployed reached $6.2 \%$ (IOM, 2010). Thus, many people prefer to work abroad, where there are more job opportunities available, along with higher salaries, such as in Malaysia, Taiwan, Saudi Arabia, Singapore, and Hong Kong (IOM, 2010). Malaysia is the main destination country for Indonesian migrant workers, with about 73,866 migrants, followed by Taiwan with about 63,018 people. The next is Singapore, Saudi Arabia, and Hong Kong with about 13.454, 12,096, and 11,755 Indonesian migrants, respectively (BNP2TKI, 2016). The most common occupation for Indonesian workers abroad during 2016 was as a caregiver, with about 44,667 people, followed by a domestic worker with about 36,335 people. The fewest jobs undertaken by the Indonesian workers were farming and forestry adviser (BNP2TKI, 2016). Hence, migration is the only way to solve the lack of employment opportunities in Indonesia, the wage differential between Indonesia and the destination country, as well as the poverty issue in the country (IOM, 2010).

The migration of Indonesian workers to other countries results in remittances, which would improve the economic status of the migrants' households in the home country. Remittances have been reported as the second largest source of external funding in developing countries (Asian Development Bank, 1992). In 2010, developing countries received USD325 billion out of the worldwide remittance flow, which was about USD440 billion. Meanwhile, Indonesia received $2.18 \%$ of the developing countries' total remittances, which is equivalent to USD7.1 billion (Asian Development Bank, 1992). Most studies reported that there is a negative relationship between remittance and poverty. Adams and Page (2005) found that a $10 \%$ increase in the per capita official international remittances would lead to a $3.5 \%$ decline in the number of people living in poverty. Yang and Martinez (2006) also agreed that remittances result in poverty reductions in developing countries. Among the other benefits of remittances, according to them, is that increasing remittances could ultimately lead to an increase in education and health expenditure at the household level. At the same time, remittances could also help to improve the access to formal financial services and enhance small business investments.

The relationship between remittances and poverty in Indonesia is illustrated in Figure 1. An increase in remittances is found to decrease the poverty level. Based on the figure, the remittance flow to Indonesia has been rising steadily since 1999 , while the poverty level has shown a declining trend. Remittance levels were relatively stable between 1999 and 2003, and then started to increase significantly in 2004 . 


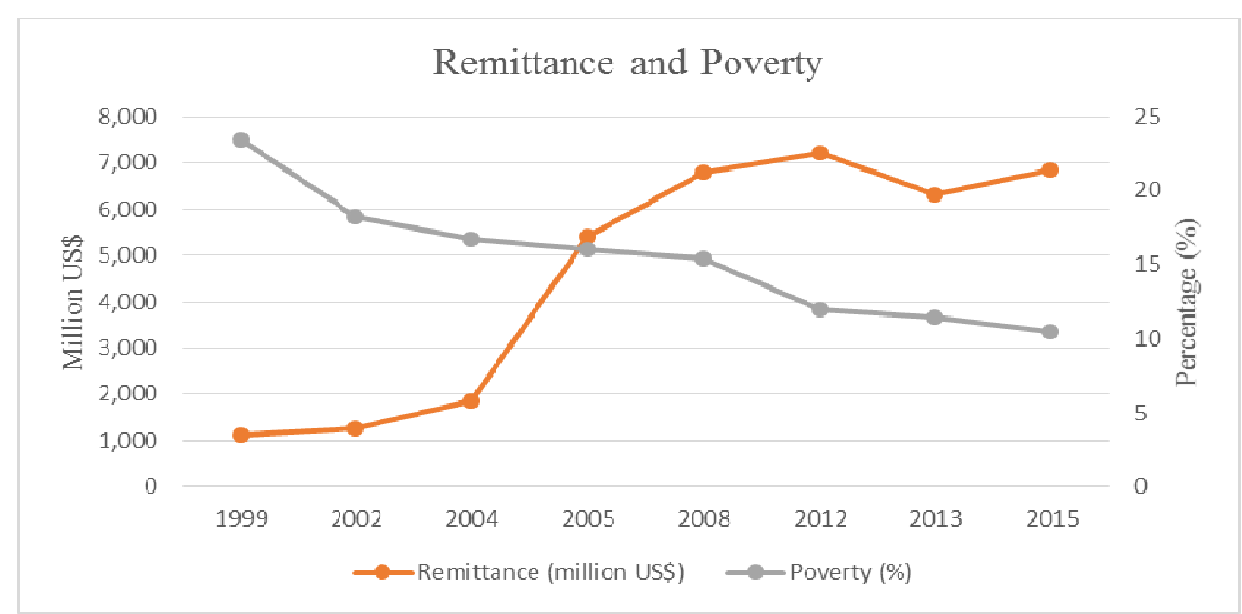

Source: World Bank (2016)

Figure 1 Remittance and Poverty in Indonesia.

From 2008 until 2012, the number of people in poverty showed a sharply decreasing trend to $4.89 \%$ of the population, which is equivalent to 28.51 million people (BPS 2016). The poverty level was relatively stable from 2012 to 2015 .

Understanding the correlation between remittances and poverty in a systematic manner is important, as there have only been limited studies reporting on this issue. The basic idea of this problem is to show the connection between remittances and poverty in Indonesia and, perhaps, to provide policy recommendations for the Indonesian government to reduce poverty through remittances.

As a means to alleviate poverty, the Indonesian government has considered sending workers abroad as one strategy. The government has been very pro-active in promoting educated workers to move outside their country by providing training. Law No. 39 of 2004 is one of the policies that the government created to protect workers abroad. This law aims to increase the workers' welfare, guarantee their safety, empower them, and protect the workers' rights (Presiden Republik Indonesia, 2012) However, the benefits from this policy are still unclear. Claims that remittances contribute positively to the Indonesian economy are still limited in the research. Therefore, in this study, further investigation of the issues is conducted.

\section{LITERATURE REVIEW}

Remittances are essential for economic development in many countries. Mostly, lowincome developing countries have a high demand for remittances when compared to highincome developing countries. In 2009, lowincome countries received $2.2 \%$ of their GDP from remittances, while the middle-income countries and high-income countries acquired only about $1.5 \%$ and $0.8 \%$ of their GDP, respectively (UNDP, 2011). Remittances have been reported to be the second largest source of external funding, following Foreign Direct Investment (FDI), for developing countries (Asian Development Bank, 1992). The characteristics of remittances, which are stable and with low volatility would help governments during a crisis or external economic shock.

Besides that, remittances could expand the economic development of some countries, if their governments channel the remittances into productive investments (UNDP, 2011), such as for education in Guatemala (Adams, 2004) and for entrepreneurship in the Philippines (Yang, 2008). Through a multiplier effect from these remittances, the remittances could also ultimately affect the poverty level.

Many researchers have examined the effect of remittances on poverty all over the world. Adams and Page (2005) examined the impact of 
international remittances towards poverty in 71 developing countries. Their findings showed that a $10 \%$ increase in capita recorded remittances led to a $3.5 \%$ decline in total poverty. They also found that poverty could be minimized by increasing the number of migrants (called international migrants) that have a job in foreign countries. A $10 \%$ increase in international migrants results in a reduction of $2.1 \%$ in the number of poor people who live on under USD1.00 per person per day.

Nevertheless, research from Adams (2009) that was conducted in 76 low-income and highincome developing countries, found that poverty can be reduced if a country sends highly skilled (educated) migrants abroad. The proficiency of migrants has a significant impact on the value of the remittances sent, which ultimately reduces the poverty rate. Regarding remittances, it is found that a country that distributes highly skilled (educated) workers generates less percapita remittances when compared to a country that exports larger numbers of lowskilled workers. A $10 \%$ increase in the distribution of high-skilled people leads to a reduction in per capita remittances by $11.2 \%$ to $19.7 \%$, while an increase of $10 \%$ in low-skilled workers will increase the remittances received by a country by $9.1 \%$ to $19.8 \%$. A possible explanation for this could be due to the tendency of the highly skilled (educated) workers to bring along their families to the destination county, thus negating the need for sending money to their country of origin. While the low-skilled worker tends to remit more money to their home country as they only see themselves as temporarily living abroad, and they concentrate on going back to their home country. Eventhough the highly skilled workers send less remittances than low-skilled workers, the findings show that the number of remittances by high-skilled workers could reduce the poverty level, since highly educated people prefer to remit their money through an investment scheme. It means that the per capita level of remittances received by a country has a positive relationship with the investment returns at home. So countries that send highly skilled workers could have the potential to reduce their poverty rate.

While in Latin America and Carribean (LAC) countries, Acosta et al. (2008) found a negative relationship between remittances and poverty. The higher the level of remittances, the lower the level of poverty. Latin America has been reported as one of the top regions that receives remittances in the world. Latin America received USD40 billion out of USD144 billion of remittances among the developing countries in 2004. Even though the reduction in poverty is relatively small, at only $0.4 \%$, it was compensated for by an increase in the income level of those migrants in the countries that they worked in. These findings are supported by Gupta et al. (2009) who researched sub-Saharan Africa. Gupta et al. (2009) found that remittances have an indirect effect on reducing poverty through a financial institution. The more the worker remits money via financial institution, such as a bank, the more of the remittance that is received by the country. The family of the worker can increase their living standard, and the remittance can be further used for investments instead of consumption. In the end, the alleviation of poverty can be achieved. However, informal remittances are a huge issue for all of the countries in the world. The more people who remit money via non-official institutions, such as sending the money through a friend or relative, the less remittances are recorded, and the World Bank would be unable to identify the real effect of remittances on poverty.

Moreover, in the case of Guatemala, Adams (2004) analyzed the impact of internal remittances and international remittances (from the United States) on poverty. The author used three different poverty measures, based on the national poverty line. First, the poverty headcount, which measures the percentage of the population that live under the poverty line. Second, the poverty gap, which measures the percentage of how far the expenditure of poor people was slipping towards the poverty line and, lastly, the squared poverty gap, that measures the changes in distribution among poor people. Through the findings, it was shown that 
the level, depth, and severity of poverty were reduced in both remittance categories, though the size of the reduction in poverty is depend on how poverty is measured. On the poverty headcount measure, the internal remittancesin household expenditure reduced poverty by $0.6 \%$ and, surprisingly, the international remittances increased poverty by $1.1 \%$. The increment in the poverty rate in this category ignores the depth of the poverty. Furthermore, the study showed that both internal and international remittances reduced the square poverty gap by $21.1 \%$ and $19.8 \%$, respectively. Thus, it can be seen that focusing on the depth (poverty gap) and severity (squared poverty gap) of poverty could reduce the poverty rate much more than only having a focus on the level of poverty (poverty headcount).

The possible justification for why the depth and severity of poverty have a much greater effect than the poverty level is due to the kinds of income (expenditure) groups that received remittances in Guatemala. When the lowest decile groups of migrants' households receive remittances, it would change their income status significantly. By improving their economic status, it will have a large effect on the poverty measurement, especially the squared poverty gap. This squared poverty gap is considered to be the number, distance and distribution of poor households below the poverty line. Therefore, a declining poverty headcount is not as much benefit as a decline in the squared poverty gap. In addition, the finding shows that internal and international remittances also had a slight impact on income inequality. It means that remittances increase the households' incomes rather than changing the income inequality.

Besides that, Taylor, Mora, Adams and Lopez-Feldman (2005) also examined the impact of remittances on poverty and inequality in Mexico. This research showed that there was a negative relationship between remittances and poverty. The increase in remittances resulted in a poverty reduction, especially in rural Mexico. Based on the poverty headcount measure, a $0.77 \%$ increase in international remittances led to decline of about $0.39 \%$ in poverty. Besides that, the regions with a high migration rate, such as the west-center, gained a greater effect on poverty reduction as compared to the low migrant-regions, such as south-southwest. It can be seen from the findings that a $10 \%$ increase in international remittances reduced poverty in the west-center and south-southwest by $1.64 \%$ and $0.11 \%$, respectively (based on FGT index). While, based on the poverty headcount measure, no significant poverty reduction was seen in the south-southwest, but a reduction of $1.68 \%$ was observed in the west-center. Regarding income distribution, international remittances tended to increase the income inequality in the rural areas while internal remittances equalized the income.

Following the above research, De La Fuente (2010) also examined the condition of poverty and remittances, from October 1998 to November 2000 in rural Mexico. This paper found that an increase in poverty would reduce the amount of remittance sreceived by the country in the long run. A country that has a high risk of poverty in the future does not have the spirit to turn remittances into higher levels of welfare for society. This paper made a suggestion to reduce the threat of poverty by classifying remittancesas the main tool for poverty allevation.

Adams and Page (2003) studied the effect of remittances on poverty in MENA countries (Middle East and North Africa) from 1980 to 2000. Based on the international poverty line, it was found that only $2 \%$ of the people in MENA countries lived below that poverty measurement. It means that only a small number of people have less than USD1 per day. International measurements are good for comparing the financial performance between countries. However, the concept still needs to be improved for developing countries. To improve the measurement of the economic condition of a country, the national poverty line needs to be applied. Poverty in MENA countries has declined significantly because of the effect of international remittances and government employment. Remittances through international migration have contributed to the improvement in the overall income in the Middle-East, while 
government employment is exploited as a means of maintaining the people in work, and therefore, of reducing the poverty rate of the country. The findings showed that both indicators have a negative relationship on poverty. From the poverty headcount measure, a $10 \%$ increase in international remittances to GDP would reduce poverty by $5.7 \%$ in MENA countries. While increasing the share of government employment by $10 \%$ leads to a poverty reduction of $6.2 \%$.

Subsequently, Chukwuoneet.al (2012) investigated the effects of remittances and poverty in Nigeria, based on data from 2004. It was found that both types of remittances, internal and international, have negative influences on poverty. The result showed that remittances reduced the level and depth of poverty by $11.14 \%$ and $9.7 \%$, respectively. It is interesting to note that different age levels influenced the amount of the remittances. Older people were more likely to get a higher remittance than younger ones. For example, males over the age of 15 would get more of a remittance than those younger than 15 . Besides that, by supporting infrastructure, such as roads and electricity, the international remittances might be increased in the future. Workers could easily cross the country cheaply and could access international migrant labor organizations via ICT (Information Communications Technology).

While in a South Asian country, Acharya and Leon-Gonzalez (2012) examined the remittance benefits on poverty and inequality in Nepal. Nepal's remittances have been reported as among the largest, based on the World Bank 2011 report (World Bank, 2011). The remittances were found to increase with GDP, amounting to about $21 \%$ from 1990 to 2009 . Hence, remittances are considered to be the biggest reason for the Nepalese people to seek work outside their country, and they are used as a tool to alleviate poverty. Meanwhile, from 1990 to 2000 , poverty declined from $42 \%$ to $31 \%$. However, Nepal had a problem in distributing the income during that time. The increment of inequality, from $0.34 \%$ to $0.41 \%$ caused Nepal to be one of the 22 countries that could not handle its income distribution. These facts left a big question mark regarding remittances, migration, poverty, and inequality, about whether or not both migration and remittances are the solutions for poverty reduction and if they are the main reasons for the increment in the income inequality in Nepal.

Accordingly, the research from Acharya and Leon-Gonzalez (2012) used two rounds comprisingof survey and panel data (1996 and 2004) to obtain an answer to the question. Regarding the poverty measurement, this study used three poverty lines, which were based on the level (headcount) of poverty, depth of poverty (poverty gap), and severity of poverty (squared poverty gap). It was found that the poverty headcount decreased by $2.3 \%$ and $3.3 \%$ in the first round, and further declined by $4.6 \%$ and $7.6 \%$ in the second round. In the case of the poverty gap measure, the poverty dropped by about $3.4 \%$ and $10.5 \%$, while based on the squared poverty gap measure, poverty declined by at least $4.3 \%$ and $12.5 \%$ at the maximum. On inequality, remittances reduced the income inequality, even though the rate of reduction was less significant. The government should solve this problem by implementing policies that protect international migration, such as by providing education to improve the skills of the workers, free help to make it easier for the workers when they apply to join the international migrant labor market, as well as by reducing the cost ofremittances. By implementing these policies, Nepal would have the potential to further reduce its poverty and inequality in the future.

In addition, Irfan (2011) who conducted research on the relationship between remittances and poverty in Pakistan, reported that in 1980, Pakistan acquired half of the remittances received in South Asia. However, from 1991 to January 2000, the remittances declined from the USD1,467 million to USD1,086 million. However, the remittances increased again in September 2008. This paper explained that the remittances, poverty, and migration have a significant relationship with each other. If the number of international migrants increases, remittances would have a huge impact in 
improving household incomes, which could simultaneously alleviate the poverty rate.

In South-East Asia, Yang and Martinez (2005) enriched the literature by analyzing the relationship between remittance benefits when related to poverty reductions in the Philippines. The study made a comparison between a household with a migrant member and a household without a migrant member, as well as considering the shock of the exchange rate during the Asian financial crisis in 1997 and 1998. The study found that the migrant's currency against the Philippine peso led to an increase in the household's remittance receipts. It was found that a $10 \%$ improvement in the exchange rate resulted in a $0.6 \%$ decline in the poverty rate. In addition, the study found spillovers in to households without migrant members. Variations at the regional level were also found, which indicated that the migrant's exchange rate caused shocks across regions of the country. In regions with a greater number of more favorable mean exchange rate shocks, poverty rates declined even in households without migrant members.

In the case of Indonesia, Adams and Cuecuecha (2010) analysed the impact of international remittances on poverty and household consumption and investment using panel data (2000 and 2007). The result shows that international remittances had a significant influence on reducing poverty in Indonesia. In 2007 , it was found that the poverty headcount dropped by $26.7 \%$ and the squared poverty gap declined by $69.9 \%$. It can be seen that these results are larger than in the previous studies conducted in other countries, such as the MENA countries. In the MENA countries, the poverty headcount was only reduced by $5.7 \%$ (Adam \& Page, 2005).

In addition, the finding of Adams and Cuecuecha (2010) showed that most Indonesian households spent their remittances as a form of a transitory type of income for the consumption of goods, such as food, which is different from Guatemala, where the remittances were used for investment purposes. These differences might be due to the big gap in the number of remittances obtained by both countries. On the other hand, the remittances received by Mexico are about twelve-fold those received by Indonesia. Hence, Mexican households prefer to spend their remittances on education and property, while Indonesian households spend them on fulfilling their basic needs and for consumption.

According to the World Bank (2010), the total remittances that Indonesia received was still less than that of the other countries. However, Indonesia had become the second largest receiver of remittances in East Asia and the Pacific by 2009. This could have a direct impact in reducing poverty if the remittances are used for local consumption and investment (World Bank, 2011). Hamidah (2013) found that Indonesian households, especially in the Babadan district, spent more of their remittances on the consumption of goods rather than for investment purposes. The total remittances used for production or investment, such as for the construction of properties (housing, farming land, and shops) amounting to $44 \%$ of the total income. Meanwhile, for the consumption of goods, around $56 \%$ of the total income was used. For the Babadan district, the remittances spent for the consumption of goods were $12 \%$ more than those used for investment purposes.

In general, Indonesia is a lower middleincome country which has many natural resources. The population reached 237.6 million people in 2010, the fourth largest after the People's Republic of China (PRC), India and the United States (Asian Development Bank, 1992). Even though Indonesia has a lot of labor and natural resources, the number of people still living in poverty is an issue that needs to be solved in this country. Due to an increase in the inflation rate in 2005, the number of poor people increased by $21.63 \%$ which is equivalent to 4.2 million people. Many small businesses closed down due to the financial problems, and this pushed the unemployment rate up by $10.45 \%$. In 2014 , the unemployment rate and poverty rate reached $6.2 \%$ and $8.25 \%$ respectively (World Bank, 2015). Though the numbers of poor people is declining gradually, the government still has to overcome this. 


\section{METHOD, DATA AND ANALYSIS}

In this study, the estimation will be based on the empirical estimation from Adam \& Page (2005). The basic growth-poverty model can be written as follows:

$$
\begin{aligned}
\log P V_{t}= & a_{0}-a_{1} \log R M T_{t}-a_{2} \log G D P_{t}+ \\
& a_{3} \log G_{t}+\varepsilon_{t}
\end{aligned}
$$

Where $\mathrm{PV}$ is the poverty measurement in the country, RMT is the remittance, GDP is per capita income, and $G$ is the Gini coefficient to measure income inequality. The remittance and GDP are expected to have a negative effect on poverty while income inequality has a positive effect. The above model is modified based on the available data, and for this research, the model can be expressed as follows:

$$
\begin{aligned}
& P V_{t}=a_{0}-a_{1} L n R M T_{t}-a_{2} L F_{t}-a_{3} L n G D P_{t}+ \\
& a_{4} G_{t}+a_{5} I N F_{t}-a_{6} \operatorname{LnEXCH}_{t}+\varepsilon_{t}
\end{aligned}
$$

$$
\begin{array}{ll}
\text { PV } & \text { : Poverty } \\
\text { RMT } & : \text { Remittance } \\
\text { LF } & : \text { Labor force partic } \\
\text { GDP } & : \text { Income (GDP p } \\
\text { G } & : \text { Gini coefficient } \\
& \text { inequality } \\
\text { INF } & : \text { Inflation } \\
\text { EXC } & : \text { Exchange rate } \\
\text { C } & : \text { Constant term } \\
\varepsilon & : \text { Error term }
\end{array}
$$$$
\text { LF : Labor force participation rate }
$$$$
\text { GDP : Income (GDP per capita) }
$$$$
\mathrm{G} \text { : Gini coefficient to measure income }
$$

In this model, the variables of remittance, income, and exchange rate will be transformed into logs, since they are not percentage data. Remittance, labor force participation rate, income, and exchange rate are expected to have a negative effect on poverty, so the expected signs of $\alpha_{1}, \alpha_{2}, \alpha_{3}$, and $\alpha_{6}$ are negative. While the Gini coefficient, as a measure of income inequality, and inflation are expected to have a positive effect on poverty, so the expected signs of $\alpha_{4}$ and $\alpha_{5}$ are positive.

This study involves a time series data set. Data were collected from existing published reports, such as the annual reports published by the Central Bank of Indonesia, the World Bank and the Indonesian Bureau of Statistic (BPS) from 1983 to 2015. All of the variables came from the World Bank's reports, except inflation which is from the Central Bank of Indonesia's reports.

The total observations of this study number 32. The dependent variable of this study is poverty, while the independent variables are remittances, the laborforce's participation rate, income GDP, income inequality, inflation, and the exchange rate.

The estimation of the long-run relationship between the variables, and the time series properties of the individual variables, are examined using a stationary test; by conducting an Augmented Dickey-Fuller (ADF) test (Gujarati, 2004). To ensure the adequacy of the fitting of the model, a diagnostic test will be conducted by examining the classical assumption tests, consisting of autocorrelation, multicollinearity, normality, and heteroskedasticity. Then the Ordinary Least Square (OLS) can proceed.

Before the OLS does proceed with a discussion of the result, it is noted that Autoregressive Distributed Lag (ARDL) analysis had been considered for this study (see Table 1, Figure 2, and Figure 3). From the result, it can be seen that there is problem by doing an ARDL regression. The result is problematic in its support of the objective of this research. One of the problems is the result does not satisfy the classical assumption test. There is a multicollinearity problem (Table 1), an autocorrelation problem (Figure 2) and normality (Figure 3 ) is not normally distributed. It is found that five out of six variables are having multicollinearity problems (Variance Inflation Factor/ VIF scores have to be less than 8 ) and the number of the $P$ value of Obs*R-Squared is less than the level of significance $(0.050)$ (Probability should be greater than the significance level). Lastly normality test found that the error term is not normally distributed, since the probability is less than the $5 \%$ level of significance $(0.02<0.05)$ (Probability should be greater than the 5\% level of significance). Hence, OLS will be used in this study instead of ARDL. The econometric result of OLS can be seen in Table 2. 
Table 1 Multicollinearity Test for ARDL

\begin{tabular}{cccl}
\hline Auxiliary & $\mathrm{Ri}^{2}$ & VIF & \multicolumn{1}{c}{ Decision } \\
\hline DLNRMT & 0.968213 & 31.4594 & There is multicollinearity \\
D(LNGDP) & 0.956885 & 23.19378 & There is multicollinearity \\
$\mathrm{D}(\mathrm{LNEXCH})$ & 0.977410 & 44.26737 & There is multicollinearity \\
$\mathrm{D}(\mathrm{LF})$ & 0.550501 & 2.224699 & There is no multicollinearity \\
INF & 0.904352 & 10.455 & There is multicollinearity \\
\hline
\end{tabular}

Source: Data Processed (1983-2015)

Table 2 Estimation Result of Regression Analysis (Dependent Variable is Poverty).

\begin{tabular}{c|ccc}
\hline Variables & Coefficient & T Statistic & Prob. \\
\hline C & 70.127 & 12.7427 & $0.0000^{*}$ \\
LN RMT & -2.5623 & -10.343 & $0.0000^{*}$ \\
D (LF) & -0.9291 & -1.6879 & 0.1039 \\
D (LN GDP) & 1.09140 & 0.3717 & 0.7132 \\
D(G) & 0.0701 & 0.27412 & 0.7862 \\
INF & 0.2437 & 3.7065 & $0.0010^{*}$ \\
D (LN EXCH) & -6.5045 & -2.3877 & $0.0248^{* *}$ \\
\hline
\end{tabular}

* denotes significance at $1 \%$ level

** and *** indicate significant at $5 \%$ level and $10 \%$ level respectively

$R^{2}=0.895315 \bar{R}^{2}=0.870190$ F-stat $=35.635 ;(\mathrm{P}$-value $=0.0000)$

Source: Data Processed (1983-2015)

\begin{tabular}{cccc}
\hline \multicolumn{4}{c}{ Breusch-Godfrey Serial Correlation LM Test: } \\
\hline F-statistic & 3.305390 & Prob. F(1,12) & 0.0941 \\
Obs*R-squared & 6.478875 & Prob. Chi-Square(1) & 0.0109 \\
\hline \multicolumn{4}{c}{ Source: Data Processed (1985-2015) }
\end{tabular}

Source: Data Processed (1985-2015)

Figure 2 Autocorrelation test for ARDL

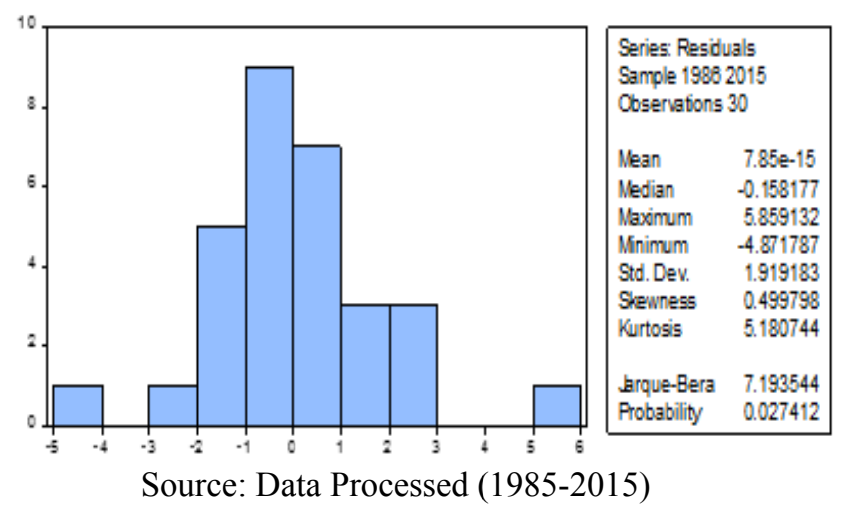

Figure 3 Normality test for ARDL

The empirical results show that LN RMT has a negative sign and is statistically significant at the $5 \%$ level. The estimation suggests that a one percent change in remittances leads to a reduction of $-2.5623 \%$ in poverty. Besides that, LN EXCH also has a negative sign and is statistically significant at the 5\% level in the regression. According to the estimation, a one percent change in the first difference of the exchange rate will decrease poverty by $6.5045 \%$. On the other hand, INF has a positive sign and is statistically significant, which means that a one percent increase in inflation caused a poverty increment of $0.2437 \%$.

However, LF and $\mathrm{G}$ are not statistically significant, although both variables have the same sign as the expected sign (negative and positive, respectively), while LN GDP is not 
statistically significant and has the opposite output to the expected sign. This implies that these variables (LF, LN GDP, and G) have no impact on poverty reduction, based on the model. In addition, the adjusted $\mathrm{R}^{2}$ is 0.870190 . This means that the poverty is $87.01 \%$ explained by the model.

Remittances have become worldwide issue since they lead to poverty reductions in many countries (Ahmed, 2010), including Indonesia. There, the government has implemented several acts to alleviate poverty. One such way is by encouraging the sending of remittances back to Indonesia. Through this act, it can be seen that the amount of the remittances has increased tremendeously, by about five times, during the period from 2003 to 2015, from USD1,489 million to USD6, 841 million. The increase in the amount of remittances automatically affects the income of the recipient households positively, since the inflow contributes to their poverty reduction. These findings are supported by the papers of Acosta et al. (2008), Adam and Page (2005), and Brown, Connell, and JimenezSoto (2014).

In addition, remittances could also become an important factor in changing the economic growth of the country through poverty reduction, since remittances are the second largest source of external finance after FDI. Remittances are part of the private welfare system that can transfer purchasing power from the rich to the poor (Gupta et al., 2009). Therefore, in the end, remittances could reduce poverty. Although remittances are statistically significant to poverty, the effect of remittances in Indonesia is still considered to below, at only $2.565 \%$, compared to other countries. Remittances have reduced poverty by $11.14 \%$ in Guatemala (Adams, 2004) and by almost $100 \%$ in Nigeria (Chukwuone et al., 2012). Moreover, it was found that poverty declined by $26.7 \%$ in Indonesia during 2007 (Adams \& Cuecuecha, 2010).

There are several possible justifications to explain the low percentage of the remittances' effect. First, the data shows that over $98 \%$ of Indonesian workers come from a low educational background or are unskilled workers, as reported by BNP2TKI (as per October 2016) in Table 3.

Table 3 Migrant Worker Based on Education Level

\begin{tabular}{lc}
\hline Elementary & 54,208 \\
Junior High School & 78,816 \\
Senior or High School & 56,633 \\
Diploma & 2,455 \\
Bachelor Degree & 952 \\
Post-Graduate & 13 \\
\hline Source: BNP2TKI (2016) &
\end{tabular}

Table 3 shows that 189,657 out of 193,077 workers have a low educational background (only until senior high school level) and only a small number of overseas workers hold a bachelor's degree, (952 people). Moreover, there are only $0.01 \%$ of the migrant workers, equivalent to just 13 people, who completed a postgraduate level education. These data shows that the majority of the Indonesian workers are unskilled, causing them to accept low wage jobs. Most of them work as caregivers (44,667 people), followed by domestic workers and operators (36,335 and 26,618 people), respectively (BNP2TKI, 2016).

Due to the low wages received, these workers can only send a small amount of money to their families, or have to use their wages to support themselves, due to the high living costs in the foreign country. Despite all this, remittances still contribute to poverty reduction, even though the amount is insignificant. However, the amount of the remittance inflow to Indonesia is inadequate to solve the poverty issue in the country.

Second, the transaction costs for remittances are typically high. These high costs might be due to the lack of competition among Money Transfer Operators (MTO). According to the World Bank's data on remittance prices worldwide (2016), the cost, which is the fee plus the exchange rate margin, to transfer RM610 from Malaysia to Indonesia, starts from RM35.96 rising to RM122.09, depending on the providers. Meanwhile, the cost of remittances 
from Singapore to Indonesia ranges from SGD7.8 up to SGD17.47 for sending SGD260. On average, the cost of sending remittances to Indonesia from Malaysia or Singapore is RM67.19 and SGD12.61. Assuming that an Indonesian migrant worker wants to send homearound RM610, the cost of the remittance will cut the total amount received by the household by RM67.19 (over 10\%). Hence, the migrant's household would only obtain the equivalent of RM542.81 in total. Similarly, for Singapore, when a migrant wants to remit around SGD260 to Indonesia, the total amount of remittance received by the family is only equivalent to SGD247.39 since the remittance costs SGD12.61. Due to these expensive transaction costs, workers prefer to send their remittances through informal bodies or nonfinancial institutions.

The third justification for the slight effect of remittances on poverty reduction is due to the unrecorded remittances. When workers send money by means other than via formal institutions, the potential remittance would be undetected. Workers commonly prefer to use informal institutions for sending money, as they have no time to go to a bank. Brown (1995a) and Brown and Walker (1995) as cited in Brown and Ahlburg (1999) reported that unrecorded remittances in Tonga and Samoa reached $25 \%$ to $60 \%$ of the total remittances. In other words, the migrants' remittances could possibly be larger than all the other foreign exchange receipts combined. Hence, unrecorded remittances have become one of the possible explanations why remittances have only had a small effect on poverty reduction.

The fourth point is Indonesian households spend more of their remittances for consumption rather than for investment purposes. Many people who live under the national poverty line will obviously use their remittances for consumption rather than investment or productive activities. It is a fact that many workers are excited about joining the international labor force. However, they are neither highly skilled nor educated, so they cannot compete with other migrants. Their competitors, that have good quality education, will get a higher salary, leaving the unskilled workers with the lower wage jobs. Hence, they need to fulfil their basic needs first using a small amount of the money obtained, rather than investing the money for education or productive activities. This is supported by the research of Hamidah (2013) who stated that there is one district in Indonesia, Babadan, which prefers to use remittances for consumption rather than investment. There, $56 \%$ of the total income was used for consumption, while the rest was used for production. In this context, production refers to building something that can produce money, such as farming land, a mini-mart, or a beauty salon. This is different compared to the other countries, such as Guatemala, where remittances are used for education and housing. The fact that the amount of the remittance received by Guatemala is larger than Indonesia is a possible reason why both countries have a different perspective on spending their remittances on productive things (Adams \& Cuecuecha, 2010).

Inflation (INF) and the exchange rate (LN $\mathrm{EXCH})$ are the other variables beside remittances that have a statistically significant influence on poverty. Inflation has a positive relationship to poverty where a one percent increase in inflation leads to a rise in poverty by $0.2347 \%$. While the exchange rate has a negative sign, which means an increase in the exchange rate by one percent will reduce poverty by $6.50 \%$.

There are several possible reasons why inflation has a positive relationship to poverty. First, when the price of goods and services rise quickly, society has to spend more money than usual, and this will affect the economic activities in Indonesia at that moment, and in the future. Economic activities, such as selling, buying, saving and investment, will be affected. However, it is a fact that everyone experiences a different rate of inflation. For instance, the price of a diaper will mainly affect the family that has young children, the price of cooking oil is a problem for the restaurant owner and a family with many members, and the price of gas is more important to someone who has to use a 
private vehicle every day, than to someone who uses a car occasionally. Even though they encounter different rates of inflation, their overall economic activities will be affected by the problem in the future.

The second point is that a lowincome family will be impacted by inflation more than a middle-income family and upper-income family. It is harder for those who have a small income to bear the rising prices since their income is not increasing as well. They have to buy goods (food) for the daily needs of the family. It is different with the middle- and upper-income families who did not experience as much disturbance in their economic activities.

According to the Indonesian Bureau of Statistics (2017), in 2014 the characteristics of households were divided into two, which are poor households and not-poor households. In the poor households' data, it was found that most of the revenue they earned was from the agricultural sector, specifically from farming, which accounted for $52.89 \%$, followed by the industrial sector, which was $6.21 \%$. Besides that, not all the poor families have a fixed income. This is proven by the data that states that the head of $11.73 \%$ of poor families does not have a job. Their educational background is the problem, preventing poor families from getting well paid jobs. Indonesia requires all its citizens to study for nine years, though $40.30 \%$ of the heads of poor households have not finished elementary school. Only $0.39 \%$ of the heads of households could reach university level. It is different with the heads of not-poor households, of whom $7.54 \%$ could finish a degree program. Hence, they have the chance of a better job with a good salary. Farming and the industrial sector are not listed as occupations for the heads of the not-poor households. Therefore, the poor in Indonesia will suffer more if the price of goods and services increases.

Next is the exchange rate. The findings of the exchange rate were supported by Yang and Martinez (2006). Their study found that an increase of $10 \%$ in the exchange rate led to a reduction in poverty by $0.6 \%$. It is shown that there is a negative relationship between the exchange rate and poverty. Yang and Martinez (2006) found that there is a connection between the exchange rate, remittances, and poverty. The exchange rate indirectly reduces poverty. When the exchange rate increases, the remittances will also go up, and in the end, the poverty will be reduced. For example, a migrant who works in Malaysia gets a salary amounting to RM1000 per month. Every month they can remit money, for instance, RM500. The household in Indonesia will receive money based on the exchange rate at that particular time. Let's say the exchange rate is IDR3000 for RM1. It means that the total sum remitted is 3000 multiplied by 500 , which is IDR $1,500,000$. However, if the exchange rate of the rupiah has increased by IDR200, so it is now IDR3200 for RM1, then the family will get IDR1,600,000. The increase of IDR100,000 will help a low-income household in Indonesia a great deal. A hundred thousand rupiah is enough to fulfil the family's basic needs. Even though the amount of poverty declines when the exchange rate is smaller ( $0.6 \%$ and $2.56 \%$ respectively), the exchange rate contributes to reducing the number of poor people in Indonesia.

\section{CONCLUSION}

From the results, it was found that three out of the six variables are significant, namely remittances, inflation, and the exchange rate. Remittances and the exchange rate have a negative relationship to poverty. When the remittances and exchange rate increase, poverty will be reduced. On the other hand, inflation has a positive relationship to poverty. Once inflation is going up, poverty will increase as well. Remittances, as a focus variable, make a contribution to reducing poverty, although the magnitude is small. The possible reasons why the contribution of remittances is low are, first, $98 \%$ of Indonesian workers have a low educational background. Second, the remittance costs are expensive, which causes the workers to remit their money through non-formal institutions, and therefore, results in many 
unrecorded remittances. Last is that Indonesian households prefer to spend their remittances for consumption rather than for investment, which therefore hampers the economic development.

\section{POLICY RECOMMENDATION, LIMITATIONS AND SUGGESTIONS}

Based on the study, the variables that significantly explain poverty in Indonesia are remittances, inflation, and the exchange rate, whereas income, income inequality, and the labor force are not statistically significant. To improve the effect of remittances on reducing poverty, there are several recommendations to overcome the remittance issue.

First, the Indonesian government should provide migrants with training to prepare them to work overseas (G20 National remittance Plan, 2015). This intensive skills training aims to improve the migrant workers' skills. The most in-demand types of occupation abroad are caregiver, domestic worker, operator, plantation worker, technician, cleaner, and housekeeper (BNP2TKI, 2016). If the migrants have already decided on a suitable job, based on their ability, the Indonesian government could understand the skills that the migrant needs. The frequency of the training would depend on the Indonesian government's budget. Besides that, the additional skills attained from the training might also become additional merits for the workers to get a higher wage. For example, if the Indonesian government trains workers to understand how to use Microsoft Office, how to turn on and shut down a computer, and other specific skills that are often listed as requirements for jobs. Furthermore, after getting that training, it might be useful even when they come back to Indonesia. The skills plus experience will be value added in a future career for the migrant workers.

Another solution is by lowering the transaction costs. Reducing the transaction fees will increase the disposable income of poor migrants and increase the incentives at home (World Bank, 2013). It may also significantly increase the annual remittance flows to developing countries. Thus it will help to increase the poverty-reducing impact of international remittances and will also encourage a larger share of the remittances to flow through formal financial channels (Adam \& Page, 2005). A further recommendation, cited by the World Bank, is that governments can encourage their postal systems and other state-owned distribution alternatives to open their networks to MTO partnerships on a nonexclusive basis. In addition, the governments should also avoid overregulation, excessive monitoring, or reporting requirements, as they could drive out smaller competitors that lack the economies of scale to absorb the costs of compliance.

Lastly, as many workers spend their time working, MTOs or other formal financial institutions, such as banks, need to take the migrants' money themselves. Indonesian banks overseas, therefore, should provide better facilities for Indonesian workers to remit money back to the country. For example, banks can create a booth which acts as a quick counter for workers who want to send money to their home country. Another possible way is that Indonesian banks overseas should offer promotions, such as cheaper charges, to encourage workers to use the formal institutions. By doing so, the institutions will gain more benefits, and the potential remittances could be recorded effectively.

Furthermore, there are several limitations regarding this research. First, this study focuses on how remittances influence poverty, while the other variables, which are the laborforce participation rate, income, income inequality, inflation, and the exchange rate, are considered as supporting variables. Hence, extensive discussions about remittances were presented, in comparison to the rest of the variables. Second is that the scope of the study was limited to Indonesia only. Third, the data were from 1983 to 2015 , thus there is only 32 years worth of data. Fourth, the poverty measure in this study used the poverty level. This research was mainly intended to find the contribution of remittances to poverty's reduction. Hence, future research could also possibly add some independent variables that relate to poverty as well, such as microeconomic or macroeconomic variables. 
Besides that, in the future, researchers could also expand the time series data since the number of observations in this research was only 32 years. Another suggestion is that future research should include panel data analysis to overcome the problems with the data set and to arrive at a more universal conclusion.

\section{REFERENCES}

Acharya, C.P., and R. Leon-gonzalez, 2012. "The Impact of Remittance on Poverty and Inequality: A Micro-Simulation Study for Nepal". GRIPS Discussion Paper, 11-26, 3(9), 1-30.

Acosta, P., C. Calderón, P. Fajnzylber, and H. Lopez, 2008. "What is the Impact of International Remittances on Poverty and Inequality in Latin America?" World Development, 36(1), 89-114.

Adam, R., and J. Page, 2005. "Do international migration and remittances reduce poverty in developing countries?" World Development, 33(10), 1645-1669.

Adams, R., and A. Cuecuecha, 2010. "The economic impact of international remittances on poverty and household consumption and investment in Indonesia". Policy Research Working Papers, (September), 47.

Adams, R.H, 2004. "Remittances and Poverty in Guatemala."World Bank Working Paper, $3418,1-36$.

Adams, R.H, 2009. "The Determinants of International Remittances in Developing Countries". World Development, 37(1), 93103.

Adams, R.H., and J. Page, 2003. "Poverty, inequality and growth in selected Middle East and North Africa countries, 19802000". World Development, 31(12), 20272048.

Ahmed, S, 2010. "Migrant Workers Remittance and Economic Growth : Evidence from Bangladesh". ASA University Review, 4(1), $1-13$.

Asian Development Bank, 1992. "Global Crisis, Remittances, and Poverty in Asia". Aldershot, U.K.: Elgar; distributed in the U.S. by Ashgate, Brookfield, Vt., 1992, pp. xxi, 275.

BNP2TKI, 2015. "TENAGA KERJA
INDONESIA" [Labor of Indonesia]. Jakarta. Retrieved from http://www.bnp2tki.go.id/ $\mathrm{read} / 11034 /$ Data-Penempatan-danPerlindungan-TKI-Periode-Tahun2015.html

BNP2TKI, 2016. "Data Penempatan dan Perlindungan TKI. [Data of placement and protection of Indonesia labor]". Pusat Penelitian dan Pengembangan Informasi, $1-42$.

Brown, R.P.C., and D. Ahlburg, 1999a. "Remittances in the South Pacific". International Journal of Social Economics, 26(1/2/3), 325-344.

Brown, R.P.C., J. Connell, and E.V. JimenezSoto, 2014. "Migrants' Remittances, Poverty and Social Protection in the South Pacific: Fiji and Tonga". Population, Space and Place, 20(5), 434-454.

Choirul H., 2013. "Dampak Remitansi Tenaga Kerja Indonesia (TKI) Luar Negeri Pada Peningkatan Investasi Daerah Asal [The Effect of Remittances onIncreasing Local Investment]". Jurnal Ekuilibrium, 11 (2), 1 14.

Chukwuone, N., E. Amaechina, S.E. EnebeliUzor, E. Iyoko, and B. Okpukpara, 2012. "Analysis of Impact of Remittance on Poverty in Nigeria", (October), 1-20. Retrieved from https://ideas.repec.org/ $\mathrm{p} / \mathrm{lvl} / \mathrm{pmmacr} / 2012-09 . \mathrm{html}$

De La Fuente, A., 2010. "Remittances and vulnerability to poverty in rural Mexico". World Development, 38(6), 828-839.

G20 National remittance Plan, 2015. "NATIONAL REMITTANCE PLAN 2015".

Gujarati, 2004. "Basic Econometric, Fourth Edition". New York.

Gupta, S., C.A. Pattillo, and S. Wagh, 2009. "Effect of Remittances on Poverty and Financial Development in Sub-Saharan Africa". World Development, 37(1), 104115.

IOM, I. O. for M, 2010. "Labour Migration from Indonesia: An Overview (English)", 2-65. Retrieved from www.iom.or.id

Indonesia Bureau Statictic, 2017. "Karakteristik Rumah Tangga [Characteristic Household]" http://www.bps.go.id/ linkTableDinamis/view/id/908 
Irfan, M., 2011. "Remittance and poverty linkage in Pakistan: Evidence and some suggetions for further analysis". PIDE Working Papers, 1-17.

Massey, D. S., J. Arango, G. Hugo, and A. Kouaouci, 1993. "Theories of International Migration: A Review and Appraisal", 19(3), 431-466.

Presiden Republik Indonesia, 2012. "UndangUndang Republik Indonesia Nomor 39 Tahun 2004 [Law no. 39 2004)]"

Taylor, J. E., J. Mora, R.H. Adams, and A. Lopez-Feldman, 2005. "Remittances, inequality and poverty: Evidence from rural Mexico". Retrieved from $\mathrm{http} / / / \mathrm{www} \cdot$.reap.ucdavis. edu/mexiconational-rural-householdsurvey/Remittances.pdf

UNDP, 2011. Towards human resilience: Sustaining $M D G$ progress in an age of economic uncertainty.

World Bank, 2010. "Improving Access to Financial Services in Indonesia". World
Bank Report, 2(52032), 1-196.

World Bank, 2011. "Migration and Remittances FactBook 2011 (Second Edition)".

World Bank, 2013. "Remittance. In Towards Human Resilience: Sustaining MDG Progress in an Age of Economic Uncertainty", 124-143. https://doi.org/ 10.1017/CBO9781107415324.004

World Bank, 2016. "Remittance Prices Worldwide.

World Bank, 2016. "Personal Remittance" https://data.worldbank.org/indicator/BX.TR F.PWKR.CD.DT

Yang, D, 2008. "International Migration , Remittances and Household Investment : Evidence from Philippine Migrants Exchange Rate Shocks", 118(528), 591630.

Yang, D., and C.A. Martinez, 2005. "Remittances and poverty in migrants' home areas: evidence from the Philippines". In Pontifical Catholic University of Chile, 81-121.

Notice: The Journal of Indonesian Economy and Business and its Board of Editors are not responsible for any errors or flaws found in this article. The authors take full responsibility for their work. 